\title{
Brexit and the Illusion of Democracy ${ }^{1}$
}

Emma Bell, Université de Savoie Mont Blanc

\begin{abstract}
\end{abstract}
The British referendum of 23 June 2016 and subsequent withdrawal from the European Union is often regarded as heralding a new democratic era for Britain as she is freed from the shackles of undemocratic EU institutions. After briefly analysing the validity of claims regarding the existence of a 'democratic deficit' in the EU, this paper examines whether national and popular sovereignty are likely to be reaffirmed by the experience of the referendum and its aftermath. It argues that, on the contrary, national sovereignty risks being further undermined as the UK, under the current conservative government, assumes a hyperglobalist position which prioritises free trade over other democratic freedoms. It also suggests that the referendum did little to revive popular sovereignty. Although the 'Leave' vote will be respected, the referendum debate itself was nothing more than a simulacrum of democracy. Far from solving the democratic deficit, the problem has only been exacerbated at a national level following the 'Remain' votes in Scotland and Northern Ireland. In the final analysis, this 'democratic moment', at least under a conservative government, was entirely illusory.

\section{Biographical note}

Emma Bell is Professor of British Politics at the Université de Savoie Mont Blanc, France. Her critical research focuses on various aspects of state authoritarianism. She has published widely in Britain and France, notably in the journals Race \& Class and in Justice, Power and Resistance, the new journal of the European Group for the Study of Deviance and Social Control. She is the author of Criminal Justice and Neoliberalism (Palgrave Macmillan, 2011) and Soft Power and Freedom under the Coalition (Palgrave Macmillan, 2015).

CONTACT: LLSH, Université de Savoie Mont Blanc, 27 Rue Marcoz, 73000 Chambéry, FRANCE.

\footnotetext{
${ }^{1}$ I'd like to thank Agnès Alexandre-Collier, Pauline Schnapper and Karine Tournier-Sol for the opportunity to present an earlier draft of this paper at a workshop organised at the University of Burgundy, Dijon, France on 27 January 2017. Many thanks also to the four anonymous reviewers for Socialism and Democracy for their thought-provoking criticisms and helpful advice.
} 
bell.emma@neuf.fr / emma.bell@univ-smb.fr

\section{Introduction}

The British referendum vote in favour of leaving the European Union was considered by many right-wing and Eurosceptic media outlets and politicians to be 'a victory for democracy'. The popular tabloid the Daily Express, on the day following the vote, encouraged other European nations to follow the United Kingdom and 'free [them]selves from the shackles of the dying European Union' (Daily Express, 2016). Boris Johnson, prominent Tory 'Leave' campaigner, now the British Foreign Secretary, regarded the vote as a defining moment in Britain's democratic history (Johnson, 2016), whilst former Prime Minister David Cameron described the referendum itself as 'a giant democratic exercise - perhaps the biggest in our history' (Cameron, 2016). Although, unlike Johnson, Cameron may not have regarded the actual result as a victory for democracy, he accepted that the will of the people 'must be respected', thus implicitly linking respect for democracy to popular sovereignty. Politicians who supported 'Leave' were particularly keen to make this link. Boris Johnson, writing just a few days after the referendum, attempted to explain the result, stating that the 'number one issue' was 'control - a sense that British democracy was being undermined by the EU system, and that we should restore to the people that vital power: to kick out their rulers at elections, and to choose new ones' (Johnson, 2016). Former UKIP leader Nigel Farage also suggested that the vote to leave the EU was about popular sovereignty, about 'the ordinary people' revolting against the elites and 'big politics' to regain control and be an 'independent, self-governing' nation (Farage, 2016).

Closely linked to this concern to give control back to the people was the desire to restore full parliamentary sovereignty so that their views could be fully expressed and 
respected via the mechanisms of representative democracy. The idiosyncratic pro-Brexit Tory MP Michael Gove made this clear when he declared, 'It is hard to overstate the degree to which the EU is a constraint on ministers' ability to do the things they were elected to do, or to use their judgment about the right course of action for the people of this country' (Gove, 2016). The need to guarantee the sovereignty of the UK Parliament has been a long-standing concern ever since former Conservative Prime Minister Edward Heath led Britain into the European Economic Community in 1973. As is wellknown, Thatcher frequently railed against encroachments on UK Parliamentary sovereignty by EU institutions, although she was prepared to grant concessions to further the aims of free trade, notably by accepting qualified majority voting in the Single European Act of 1986. Despite David Cameron's initial desire to set aside such issues and stop his party from 'banging on about Europe' (Cameron, 2006), on becoming Prime Minister he introduced the so-called 'referendum lock' under the European Union Act 2011 requiring that a referendum be organised prior to any further transfer of powers from the UK Parliament to EU institutions. The issue of parliamentary sovereignty was also central to the negotiations of Britain's terms of EU membership carried out prior to the 2016 referendum: Cameron notably secured a commitment from the EU that Britain would be exempt from 'ever closer union' written into future EU treaties.

Yet, the result of the referendum reflects the widespread belief that only an exit from the European Union will be sufficient to restore the apparent loss of UK parliamentary sovereignty and thus revive democracy in Britain. Such a viewpoint betrays a rather narrow understanding of democracy, limited to restoring the freedom of British parliamentary institutions. Popular sovereignty is confounded with parliamentary sovereignty, overlooking the fact that the British electoral system and 
political institutions themselves are often profoundly undemocratic, denying the effective participation of ordinary people in decision-making processes and failing to protect their interests. This paper regards parliamentary sovereignty as important: national governments ought to be free to take decisions and implement policies in the national interest. Yet, it also stresses the importance of popular sovereignty which must mean much more than simply giving people the power to vote in elections and referendums. It entails involving them in meaningful political debate and decisionmaking processes and ensuring that they can hold elected leaders to account at all times, not just once they are called upon to vote. In short, in means genuine empowerment at a local and national level.

This paper seeks to examine whether the UK referendum and the looming Brexit can really be regarded as a victory for democracy in Britain. It begins by examining the so-called 'democratic deficit' in the European Union. This discussion is brief as an abundance of research papers have already been written on this question. Yet, it is necessary to identify the key problems in order to assess whether Brexit can address them. It then moves on to examine popular and parliamentary sovereignty in turn, analysing to what extent they are likely to be boosted post-Brexit to bring about a democratic revival. It is suggested that such a vision is largely illusory, not least because of the failures inherent in British democracy itself.

\section{The 'democratic deficit' in the EU}

There have long been concerns about the capacity of the EU to respect democratic principles, even if little has been done by EU officials to address these concerns. Already in 1979, the British political theorist David Marquand expressed concern about the 'democratic deficit' in the EU, by which he meant the lack of democratic legitimacy in its 
institutions (Marquand, 1979). The EU itself also recognises the issue, including the term 'democratic deficit' in its glossary of EU terms. It defines it as follows:

a term used by people who argue that the EU institutions and their decision-making procedures suffer from a lack of democracy and seem inaccessible to the ordinary citizen due to their complexity. The real EU democratic deficit seems to be the absence of European politics. EU voters do not feel that they have an effective way to reject a 'government', they do not like, and to change, in some ways, the course of politics and policy. (European Union, 2017)

Perhaps it is simply impossible for a supranational structure such as the EU to involve the people in decision-making processes in any meaningful way. It is certainly true that there are high levels of dissatisfaction with how democracy works in the EU, as would appear to be reflected in low voter turnout for elections to the European Parliament. Electoral turnout stands at little over 35\% in the UK compared to an average EU turnout of 42.6\% (UK Political Info, 2017). Furthermore, according to recent Eurobarometer figures measuring public opinion across member states, $41 \%$ of respondents are dissatisfied with the way democracy functions in the institutions of the EU - this is a significant percentage even if it is slightly lower than the percentage of respondents declaring themselves satisfied (46\%) (European Commission, 2015, p. 139). Interestingly, the figures for the UK were slightly lower than the EU average (38\%) compared to Greece where respondents showed the highest levels of dissatisfaction (66\%) (European Commission, 2015, p. 140). Yet, these figures from the UK are to be sharply contrasted with the percentage of British respondents declaring themselves satisfied with how democracy works within the UK (63\%) (European Commission, 2015, p. 138). It would thus seem that a majority of British people think that British democracy functions better in the UK than in the EU as a whole, which may go some way to explaining the belief that leaving the EU may be good for democracy. 
This perceived democratic deficit with regard to EU decision-making procedures may be explained to some extent by the functioning of the European Commission, the executive arm of the European Union. It is often suggested that the Commission is made up of 'unelected bureaucrats' who pass laws without democratic consent. The claim that the 28 European Commissioners are unelected is not entirely true. Whilst they are not elected directly by the people, they are elected indirectly by their representatives. Indeed, commissioners are appointed by the governments of all member states. Nominations are approved by the European Parliament which is directly elected by the citizens of the EU and retains a power to remove the Commission via a vote of no confidence, even if this power has never actually been used. Nonetheless, this power is highly limited as the Parliament cannot reject an individual nominee or sack an individual commissioner. Furthermore, as the UK's Electoral Reform Society points out, there remains 'a significant gap between the Commission and the people' as the channels of representation are 'byzantine' (Terry, 2014, p. 36). Indeed, there is little transparency in the process of electing commissioners. Decisions are made behind closed doors and often involve negotiation with other national governments.

What of the claim that commissioners pass laws without democratic consent? Again, this is not entirely true. Commissioners do not in fact pass laws but merely propose laws which are then examined by the European Parliament and, since 2006, by national parliaments. Indeed, under the Lisbon Treaty, the latter have an opportunity to express their disapproval of legislative proposals via a mechanism known as 'reasoned opinion' if they think that the proposals violate the hallowed principle of subsidiarity ${ }^{2}$. If

\footnotetext{
${ }^{2}$ Defined as 'the principle whereby the EU does not take action (except in the areas that fall within its exclusive competence), unless it is more effective than action taken at national, regional or local level. It is closely bound up with the principle of proportionality, which requires that any action by the EU should
} 
one third of parliaments issue a 'reasoned opinion' within eight weeks of receiving the legislative proposal from the Commission, a 'yellow card' is issued, in which case the Commission is obliged to revise the proposal. Nonetheless, the system in practice seems quite ineffective due to the difficulty in achieving sufficient consensus among member states to trigger a yellow card. Indeed, the very first yellow card was issued in 2012 and only one further yellow card has been issued since then. This prompted David Cameron to successfully negotiate a new 'red card' system in his pre-referendum negotiations with the EU. This means that a legislative proposal from the EU Commission can be rejected if $55 \%$ of member states reject it. This is however a very high threshold which, given experience with the yellow card system, will likely be very hard to obtain.

\section{The European Parliament: The EU's democratic arm?}

Yet, even if the European Commission is considered to be weak on democracy to the extent that it is not particularly representative of either popular or parliamentary sovereignty, the European Parliament might be considered to make up for this democratic deficit to some extent. Given that the 766 MEPs are directly elected by the citizens of European member states, the European Parliament is often considered to be the one European institution that does not lack democratic legitimacy. Indeed, it may even be regarded as more democratic than the UK Parliament given that it is elected via a system of proportional representation. One diplomat who has worked as an advisor to the European Commission even suggests that, far from suffering from a democratic deficit, the European Union has a 'democratic surplus' but that democracy fails due to low voter turnout (Cooper, 2016). Yet, this low voter turnout might be explained by the

not go beyond what is necessary to achieve the objectives of the Treaties'. See http://eurlex.europa.eu/summary/glossary/subsidiarity.html (accessed 16 January 2016). 
fact that the voting system is not so democratic as it may appear at first sight. Indeed, as Democratic Audit UK points out, 'the voting system for the EU elections puts power in the hands of parties, rather than citizens, allowing party bosses to draw up candidate lists behind closed doors' (Mortimer, 2016). Indeed, in the UK citizens only have the possibility to vote for parties rather than for specific candidates, despite the fact that research suggests that voter turnout tends to be lowest in countries which practice the system of closed lists (Mattila, 2003).

Yet, even though there are democratic problems with the current functioning of EU institutions such as the Commission and the Parliament, this does not automatically mean that they have a negative impact upon democracy at a national level, as is often suggested by detractors of the EU (even if, as suggested below, the actions of EU officials can). In fact, the very opposite might be the case. National parliaments can have a negative impact on how democracy functions within the EU. This is particularly true of the United Kingdom.

\section{National sovereignty against democracy?}

Far from being side-lined by European institutions, the UK government has long had a significant influence over the policies they have pursued. As Pauline Schnapper has pointed out, the UK has left a strong 'ideological footprint' on the EU, notably in defending free trade and breaking down barriers to competition (Schnapper, 2014, pp.99-103). The Single European Act 1986, endorsed by Margaret Thatcher and pursued by British policy-makers, can be seen as a major step towards completing the single market, especially via the introduction of qualified majority voting to force reluctant member states to open up their markets to competition. The Lisbon Treaty signed in 2007 was also significantly influenced by UK neoliberal priorities. Notably, it 
introduced a comprehensive ban on anti-competitive agreements and forces services still held by the public sector to compete with those that have been privatised. The Treaty subjects all economic services, including public services, to new 'economic and financial conditions' and seeks to ensure that 'competition is not distorted'. The UK has also continued to push for the completion of the single market in the energy, digital and service sectors of the economy whilst simultaneously seeking to open EU markets up to global markets, notably by securing its objective of opening talks between the EU and the United States on the Transatlantic Trade and Investment Partnership (TTIP) (although at present no agreement has been signed). British influence in these areas has been facilitated in particular by the appointment of British officials to strategic roles within the institutions of the Union (Cassen, 2016), notably Vicky Ford, former financial adviser for J P Morgan, currently Chair of the Internal Market and Consumer Protection Committee in the European Parliament, and Jonathan Hill, a former lobbyist for the financial sector, who occupied the post of Commissioner for financial markets from 2014-16.

Of course, Britain could not have secured these reforms without the support of key allies in EU institutions and in other member states. The key point is that such reforms have led to a significant erosion of democracy that was not imposed from outwith Britain's borders by supranational institutions but rather under the impulsion of successive British governments (amongst others). The drive to break down barriers to free trade, given renewed impetus in the Lisbon Treaty, led to a blatant denial of popular sovereignty despite the Treaty calling for EU institutions to have 'open, transparent, and regular dialogue with representative associations and civil society' (article 11). As is well-known, the Treaty built on previous proposals for an EU Constitution which were rejected when put to the popular vote via referendum in 
France and in the Netherlands in 2005. When the Irish voted against the Lisbon Treaty in 2008, they were 'asked' to vote again in 2009. The British did not even get a chance to vote.

Popular sovereignty was also denied in negotiations regarding the TTIP as civil society organisations were marginalised. Analysing data on all closed-door meetings held between lobbyists and the European Commission's trade department in the first stage of negotiations on the TTIP from January 2012 to February 2014, the Corporate Europe Observatory found that $88 \%$ of all meetings were with corporate lobbyists whilst just 9\% were with civil society organisations (Corporate Europe, 2015). Yet, the EU adopts a very broad notion of 'civil society' which may include corporations, lobbies and employers' groups alongside trade unionists and radical citizens' groupings (Robert, 2016). There is no requirement that these groups be represented in equal proportions. This is rather like David Cameron's notion of the 'Big Society' in Britain which encompassed third sector groups together with private companies, with the latter holding significantly more power than the former, allowing them to dominate bids for government contracts to run public services for example (Bell, 2015).

The danger for democracy is that 'civil society' has become 'the self-appointed spokesperson for the citizenry' whilst the people becomes 'nothing more than another pressure group amongst others' (Robert, 2016). Such an idea has been promoted by the Anglo-American idea of 'good governance' which, in theory if not in practice, encourages 'less State' as the tasks of government are increasingly shared with alternative public and private actors (Bell and Hindmoor, 2009). In practice, this has led to a dominance of private corporate actors over individual citizens, something which has been identified, notably by Colin Crouch, as eroding the institutions of democracy in the nation state and beyond (Crouch, 2012 [2004]). The trend has been exacerbated by the fact that 
corporate actors are no longer just part of 'civil society' broadly defined, but also part of the polity itself, helping to make and implement public policy (Crouch, 2010, p. 167). But they are not directly accountable to the demos, thus posing a challenge for representative democracy.

Within the EU, the rise of the corporation, boosted by Anglo-American neoliberalism, contributed to the denial of popular and indeed parliamentary sovereignty in the context of the 2008 financial crisis and subsequent recession. The austerity response was led not by the democratically elected European Parliament but by the 'troika': the European Commission, the European Central Bank and the International Monetary Fund. Whilst it was said to have been unduly influenced by Germany and old ideas of German ordoliberalism (see, for example, The Economist, 2015), it was just as likely to have been influenced by neoliberalism as practiced in the UK (Wren-Lewis, 2016a). There is a growing body of opinion that views the drive for austerity in the UK and in the EU as being driven more by ideology than necessity and that argues that austerity may even have delayed recovery (Wren-Lewis, 2016a; IMF, 2014). Furthermore, the economic research that was used to justify austerity has since been discredited even though the austerity drive continues apace (Krugman, 2015). Wren-Lewis has convincingly argued that austerity was a pretext to reduce the size of the State (2016). Whilst the theory that the State has been shrinking in recent years is highly questionable (Bell, 2015; Bell, 2017), he is correct that austerity has allowed the State to become smaller in the sense that it has handed over the management of a wide number of previously public services to the private sector.

This is true in the UK where the value of outsourced public services has increased significantly in recent years to reach more than twice their value in 2000 - estimated at well over £80bn (Deloitte, 2016). In Greece, the troika has pushed this policy to its 
limits, imposing a vast policy of privatisation. In summer 2015, the Greek government agreed to sell off $€ 50 \mathrm{bn}$ of public assets. The official justification for such a policy is to enable the Greek government to reimburse its creditors. However, the privatisation programme so far suggests that the principal aim has been to ensure maximum profit for investors. For example, under one of the largest privatisation programmes so far involving the concession of 14 airports to a private consortium dominated by the German group Fraport, the Greek government has had to guarantee optimal conditions for the latter, notably exempting the company from paying local taxes, whilst committing itself to bear the costs of any employees it makes redundant (Kadritzke, 2016). The troika also insisted that the least profitable airports would be excluded from the deal. Furthermore, corporate interests were supported via Greek bailout funds. Thomas Fazi claims that more than $80 \%$ of these funds were used to rescue the financial sector, either directly or indirectly, in what he describes as 'phase two of the bailout of Europe's financial sector' (2016).

Whilst there is some support for austerity programmes in the $\mathrm{UK}^{3}$, opposition in Greece was significant: in July 2015, $61 \%$ of Greeks voted in a referendum against the austerity-imposing bailout package proposed by the troika. Yet, in striking disregard for popular and parliamentary sovereignty, in negotiations between the newly-elected leftwing Greek government and the troika following the referendum, the German Minister of Finance Wolfgang Schäuble refused to renegotiate the offer, stating 'Elections cannot be allowed to change an economic programme of a member state' (Schäuble, 2015, quoted by Varoufakis, 2016). Such refusal to listen to the voice of the citizenry as expressed through popular elections and the referendum could only fuel the widespread

\footnotetext{
${ }^{3}$ YouGov polls carried out between 2011 and 2015 show that a majority of British people thought that austerity policies were being too quickly and unfairly implemented but a consistent majority (between 55 and 60\%) accepted these policies as 'necessary'. See SPERI (2015).
} 
feeling across Europe that unelected EU officials were behaving in an entirely undemocratic manner, regardless of whether they supported austerity measures or not. It seemed that national governments, particularly in southern Europe, were left powerless before the troika. Yet, some national governments did have significant influence over the policies it enforced. Whilst the influence of Germany was undoubtedly great, the UK helped to create a particular ideological climate in which austerity was regarded as the best way of handling economic crisis in spite of overwhelming evidence to the contrary. If popular and parliamentary sovereignty were ignored in the case of Greece, the UK government must therefore bear its share of the blame. Nonetheless, it can be asked whether the specific challenges facing Britain outside the EU may lead her to act differently with regard to respect for democracy within her borders. The next section focuses on the chances of a revival of democracy post-Brexit, looking first at the ways in which parliamentary democracy might be restored. It then discusses whether or not popular sovereignty is likely to be respected.

\section{Reviving democracy?}

\section{Restoring sovereignty to Parliament}

The issue of parliamentary sovereignty was considered of vital importance in the referendum on EU membership. For Theresa May, the idea (justified or not) that EU membership limited the ability of the British people to directly hold their government to account was one of the principal reasons why the majority voted to leave (May, 2017). This affirmation echoes Lord Ashcroft's immediate post-referendum analysis which found that $49 \%$ of voters supporting 'Leave' did so to support 'the principle that decisions about the UK should be taken in the UK' (Ashcroft, 2016). In due dereference to the principle of parliamentary sovereignty, May committed herself to put the final 
deal that Britain negotiates with the EU on leaving the EU to a vote in both houses of parliament (May, 2017). The Labour Party manifesto from the latest general election in June 2017 also promises 'to guarantee that Parliament has a truly meaningful vote on the final Brexit deal' (Labour Party, 2017). So, there are certainly high hopes that Brexit will lead to a restoration of parliamentary democracy in the UK.

Yet, this depends on whether the final Brexit deal will be negotiated by the Labour or the Conservative Party. Rather ironically, it would appear that the latter will take the lead here, despite having failed to win either a majority of the popular vote or parliamentary seats at the last general election. Even though May's position is extremely fragile after having unnecessarily called a general election and losing the conservatives' parliamentary majority, under the Fixed Term Parliaments Act 2011 it is possible that there will not be another general election until 2022. But the political situation remains highly unstable and a vote of no confidence could trigger an election before the end of a five-year term. Should May, or any other conservative Prime Minister for that matter, end up ultimately determining the final Brexit deal, there are considerable threats to parliamentary sovereignty. The conservative vision of a 'truly global Britain' following Brexit, as outlined in May's January 2017 speech on Brexit, can be regarded as heralding a return to a hyperglobalist position for the conservatives, defined by Baker and Schnapper as follows:

a belief that national and even regional economies are becoming deterritorialised, global and transnational, through the increasingly free mobility of capital across national boundaries, promoted by transnational corporations, especially in the financial, knowledge-based and communications industries, and also by increasing manufacturing interdependency and outsourcing between different national economies (2015, p. 145)

This suggests that for Britain to be successful in the international economy, she needs to break free from the shackles of an ever more integrated EU and its market regulations 
which are regarded as a threat to global competitiveness (Baker and Schnapper, 2015: 146). Free from EU constraints, Britain can, in the words of May 'get out into the world' by forging new free trade agreements with countries across the globe, including with the EU (May, 2017).

In place of the Single Market, May hopes to 'pursue a bold and ambitious Free Trade Agreement with the European Union' (May, 2017). While this would leave the UK Parliament free to reject the inherent 'four freedoms' of Single Market membership (freedom of goods, capital, services and people), it will surely be obliged to accept a number of constraints which risk severely limiting parliamentary sovereignty. This will also be the case with the multitude of free trade agreements the British government plans to negotiate with other countries. Indeed, all free trade agreements with other nations necessarily involve certain compromises being made with regard to national sovereignty. The recently negotiated Comprehensive Economic and Trade Agreement (CETA), signed between the EU and Canada on 30 October 2016, is a case in point. If ratified, the agreement will oblige national governments to open up their public services to bids from private companies based in signatory states, thus clearly limiting their sovereignty over economic policy. Nonetheless, significant concessions were made, notably following opposition from the Belgian regional assembly of Wallonia, and the agreement will not be enforced if all member states and the European Parliament do not ratify it. Notably, the Investor State Dispute Settlement (ISDS) mechanism has been dropped from the agreement at the time of writing in an attempt to secure EU-wide consensus on the agreement. ISDS mechanisms are built in to existing free trade agreements such as the North America Free Trade Agreement (NAFTA) and there were also attempts to incorporate them into the TTIP that the British government was so keen to promote. Such arrangements effectively enable companies to sue elected 
governments if they adopt policies which, whilst in the public interest, limit their profit margins. In practice, this means that corporations are empowered at the expense of ordinary citizens or even democratically-elected politicians, with obviously negative consequences for both popular and parliamentary sovereignty.

Whilst the EU has shown some effective resistance to free trade agreements which threaten national sovereignty, notably stalling TTIP negotiations, it is unlikely that the UK government will follow suit. On the contrary, May has made it quite clear that securing such agreements is a top priority. Ideologically, the current conservative government is likely to make whatever concessions are necessary in order to promote free trade. It was certainly prepared to do so in pushing for the TTIP. Following a hyperglobalist position, free trade is likely to trump sovereignty every time. Furthermore, even if the UK did want to resist aspects of free trade deals that might limit sovereignty, she will find herself in a very weak negotiating position against much larger nations than herself and will be forced to accept the rules and regulations of countries she wishes to export to. She may also find herself forced to be more flexible with regard to immigration policy: the EU is not the only trading block that expects at least a certain degree of free movement of people and labour to accompany free movement of capital and goods. In a visit to India in November 2016, the Prime Minister was warned that current restrictions on Indian migrants could be a stumbling block for any future trade deal (Boffey \& Doshi, 2016). It is also unlikely that there will be sufficient democratic consultation on free trade agreements given the apparent rush to push these through. On the morning after May's Brexit speech, the International Trade Secretary, Liam Fox, claimed that he had already begun discussing informal trade deals with at least 12 countries 'to see how [Britain] can remove barriers to trade and investment to their mutual benefit' (Fox, 2017). Even before Trump's official inauguration, he revealed in an 
interview with Michael Gove, a key member of the House of Commons 'Exiting the European Union Select Committee', that he wanted a trade deal that would be 'signature ready' by 2019 when the UK is expected to leave the EU (Trump, 2017a). In his most recent meeting with Prime Minister Theresa May, at the G20 meeting in Hamburg in July 2017, he stated that a trade deal with the UK will be concluded 'very, very quickly' (Trump, 2017b).

Nevertheless, conservative proponents of the hyperglobalist position suggest that the nation state does still have a vital role to play: that of ensuring that markets are as free as possible (Baker and Schnapper, 2015, p. 146). Yet, this is a very limited view of parliamentary sovereignty and certainly not one that is capable of squaring the latter with popular sovereignty, a point we shall return to below. It is also a rather outdated view that is ill-adapted to the realities of the modern world. It seems to ignore the fact that trading partnerships can no longer be built on domination, as was once the case for Britain, but on genuine partnership and coordination. This will entail Britain redefining its international position in a way that is fit for a networked world, not based on past glories and predicated upon maintaining narrow self-interest (LSE Diplomacy Commission, 2015). It will thus necessarily have to sacrifice a degree of national sovereignty.

However, in the event of a Labour victory following a new general election before the conclusion of the Brexit deal, there is a real chance that parliamentary (and, as we shall see, popular) sovereignty might be restored. Like the conservatives, Labour values Britain's European and international trading relationships. It aims to retain unrestricted access to EU markets for goods and services and it will also seek to remove trade barriers between Britain and other nations. Yet, unlike the conservatives, it is committed to ensuring that human rights and social justice are protected in trade policy. 
Importantly, when it comes to protecting sovereignty, it will not allow national public services to be undermined by multinational corporations, notably by opposing parallel investor-state dispute systems for multinational corporations (Labour, 2017). It also opposes May's vision of what it describes as a 'bargain basement Britain' whereby the country would be engaged in a race to the bottom to offer the lowest tax rates and levels of regulation to international corporations. On the contrary, it seeks to retain EU-derived labour protections, consumer rights and environmental protections which act as some restraint on corporate power that is one of the biggest threats to democracy at present.

Labour is thus in favour of what is popularly termed a 'soft Brexit' - a stance which apparently contributed to a significant extent to its recent electoral success (Walker, 2017). It will continue a strong partnership with the EU. This may mean that it will have to sacrifice some degree of parliamentary sovereignty as it accepts certain conditions in exchange for single market access. Yet, for Labour those conditions relative to labour market and workplace regulations for example - may enhance popular sovereignty to the extent that they enhance citizen power over that of corporations. Labour seems committed to retaining these more democratic aspects of EU policy. This may even have a positive effect on the EU as a whole, strengthening the legitimacy of such regulations. Indeed, senior Labour Party figures close to Corbyn, notably the shadow Chancellor John McDonnell, have demonstrated their commitment to reforming the EU in a positive direction. McDonnell was notably a signatory to the declaration calling for Britain to stay in the EU in order to reform it launched by the pan-European popular movement to democratise the EU - DIEM25.

Labour also differs from the conservatives in its conception of parliamentary sovereignty itself. May might recognise that the concept has changed somewhat following devolution (May, 2017), but she does not recognise the fundamental change 
that has occurred in recent decades, namely that parliamentary sovereignty can only be recognised as legitimate so long as popular sovereignty is respected. These two aspects of sovereignty currently have something of an antagonistic relationship in Britain (and beyond).

\section{Respecting popular sovereignty}

According to Vernon Bogdanor, the referendum on Britain's membership of the EU represented something of a victory for popular sovereignty and even, to some extent, threatened the very sovereignty of Parliament itself:

The referendum has now established itself as a third chamber of Parliament, issuing legislative instructions to the other two. The sovereignty of the people is trumping the sovereignty of Parliament. The Commons is required, perhaps for the first time in its history, to follow a policy to which around three quarters of MPs are opposed. The sovereignty of Parliament is now to be constrained-not legally, of course, but for all practical purposes-not by Brussels but by the people (Bognador, 2016, p. 350)

Indeed, the referendum stood as a counter-example to the apparent 'democratic deficit' of the EU and its institutions. Politicians could ignore the result at their peril, especially given the high voter turnout (over $72 \%$ ), at least compared to recent parliamentary elections (between 59 and 66\%). There was no question that the referendum could be considered as merely advisory for either the conservatives or Labour. Hence, both politicians and the media were outraged when the High Court ruled that there would have to be a vote in Parliament before article 50 could be triggered since 'a referendum on any topic can only be advisory for the lawmakers in Parliament unless very clear language to the contrary is used in the referendum legislation in question' (R. (Miller) v. Secretary of State for Exiting the European Union [2016] EWHC 2768 (Admin)). UKIP MP

Douglas Carswell complained that the ruling was an example of 'shocking judicial activism - these judges are politicians without accountability' (Carswell, 2016) whilst 
the Daily Mail memorably condemned the High Court judges who delivered the decision as 'enemies of the people' who 'declared war on democracy' (The Daily Mail, 2016). When the Supreme Court upheld the decision on 24 January 2017, The Daily Mail lamented, 'Yet again the elite show their contempt for Brexit voters' (2017).

The principle of parliamentary sovereignty would appear to have been reaffirmed. This does not, however, mean that popular sovereignty can or will be ignored. It would seem that the current government is fully aware that: 'Many voted to leave because they viewed politicians as separate from them and their concerns. If they now feel politicians have ignored their instruction to leave the EU this will lead to widespread, and understandable, anger' (Dodds, 2016, p. 362). This would of course undermine democratic legitimacy at home.

The very fact of calling a referendum might be regarded as further proof of the UK government's respect for popular sovereignty. Yet, the motivations for calling the referendum were far from democratic. Indeed, it was much more about avoiding intraparty tensions by satisfying the demands of the Tory backbenches by adopting 'rhetorical populism' (Alexandre-Collier, 2016).

As for the referendum debate itself, this was far from democratic as it failed to engage the public in a meaningful public debate. It is now recognised that the campaign was based on a great deal of false information, most memorably the Leave campaign's claim - subsequently branded 'a mistake' by Nigel Farage (The Telegraph, 2016) - that $£ 350$ million a week that was reportedly spent by the UK government on the EU could be spend on the NHS after Brexit. Overall, it was an essentially negative debate, described by openDemocracy founder Anthony Barnett as 'a conflict between two forms of anti-Europeanism', 'a disagreement over how to have as little as possible to do with [Europe]' (Barnett, 2016, p. 87). The rhetoric of 'taking back control' over Britain's 
borders was essentially populist, responding to knee-jerk sentiments about immigration rather than encouraging reasoned debate about the issue. For Barnett, such discourse was 'no more than a dog whistle for racism' (Barnett, 2016, p. 264). Perhaps the most striking example of this was UKIP's campaign poster depicting a long queue of refugees alongside the caption 'Breaking Point: The EU has failed us all - we must break free of the EU and take back control of our borders'.

The media also failed in its role to inform and educate the public about the issues at stake. The British tabloids, already famous across the world for their Euroscepticism, weighed into the debate with scaremongering and misinformation. Yet, such poor reporting was not the sole preserve of the tabloid media. The so-called 'respectable' media, like the $\mathrm{BBC}$, also failed to present the debate in anything other than Manichean terms. This can be partly explained by the concern with 'balance' which means that even the most ludicrous claim was 'balanced', 'not interrogated or explored. Once stated, [it] could apparently only be countered' (Seaton, 2016, p. 335). This means that all views are treated equally, whether one is more likely to be supported by factual evidence or not. Wren-Lewis has explained how this obsession with 'balance' led to a 'politicisation of the truth' in the Brexit debate whereby economic arguments were neither fully explored nor challenged but simply used to support political ends (Wren-Lewis, 2016b).

The referendum was not therefore a symbol of democratic revival in Britain. It was a 'bad' referendum that failed to inform the public and engage them in intelligent debate about alternative futures (Barnett, 2016, p. 124). It has often been contrasted with the 2014 referendum on Scottish independence which, by contrast, is seen as having been characterised by genuine democratic engagement. Not only did the turnout of $84.1 \%$ beat all turnouts in national UK elections since universal suffrage began but the campaign itself was more positive, reflecting genuine engagement with everyday issues 
facing the Scottish people. Adrian Pabst reflects the opinion of many when he writes, 'the two-year campaign re-energized politics and re-engaged the citizenry after decades of popular alienation and anger' (Pabst, 2014, p. 8). It was a campaign that gave a voice to the Scottish people that had largely been denied, at least until the devolution process began in 1997. The most recent referendum on EU membership has taken that voice away from the $62 \%$ who voted to remain. Indeed, the Brexit was not so much a Brexit as an Exit - an English exit - on account of the fact that it was largely English votes that swung the result in favour of 'leave' (Barnett, 2016). A clear democratic deficit has now opened up in Scotland as a result of the EU referendum (McCorkindale, 2016). Despite May's assurances that it will be possible to 'strengthen the precious union between the four nations of the United Kingdom' (May, 2017), it will be very hard for her do so whilst that democratic deficit is perceptible in Scotland. There has been no attempt to address the irony of Westminster politicians unelected by the Scottish people forcing Scotland to leave a European Union that is apparently dominated by 'unelected bureaucrats'. Although May has included ministers from Scotland, Wales and Northern Ireland a Joint Ministerial Committee on EU Negotiations, it has been clear so far that the Brexit negotiations will be led from the centre. Popular sovereignty in Scotland is therefore being denied. May seems oblivious to the further irony that whilst she asks for European states to respect the different political traditions of the UK, she ignores the different political traditions of Scotland which place much more emphasis on popular sovereignty, as affirmed in the Claim of Right 1989. Similarly, in Northern Ireland, where $56 \%$ of the population voted to remain in the EU, there is a lack of democratic legitimacy for Brexit. For the people of Scotland and Northern Ireland, slogans about 'taking back control' also carry more than a hint of irony (Tonge, 2016, p. 342). 
The people of England and Wales are, however, unlikely to fare much better. Although the looming Brexit represents the majority popular view in those two nations, their voice risks being drowned out by corporate interests which, as suggested above, are likely to be favoured in the new trade deals that are to be negotiated in the wake of Brexit. Already, in the UK, the power of corporations dwarfs that of the citizenry (as is of course also the case in the EU). Their participation in the political process is reduced largely to voting whilst corporations are now part of the political process itself. They do not just lobby government but also provide consultancy advice that helps shape policy and, thanks to the flourishing outsourcing industry, provide public services and determine who might have access to them (Bell, 2015). Meanwhile, citizens find that their basic social and economic rights are eroded. The primary role of government is no longer to protect the citizenry by guaranteeing minimum social and economic security but to expand and create new markets for the private sector. This is essentially what the Prime Minister means when she promises that Britain will be 'one of the firmest advocates for free trade anywhere in the world' (May, 2017).

Again, a future Labour victory may provide a positive alternative. As outlined above, Labour would seek to limit corporate power. Furthermore, unlike the conservative government, it shows some awareness of the democratic deficit in Britain, promising in its manifesto to address the problem, notably by subjecting private companies running public services to more democratic scrutiny and promising to establish a 'Constitutional Convention' with the aim 'to examine and advise on reforming of the way Britain works at a fundamental level' (Labour Party, 2017).

\section{Conclusion}


To regard the British vote to leave the European Union as a victory for democracy is to adopt a very narrow view of democracy. For the conservative government, democracy is fulfilled so long as the people are given a chance to express their opinions through the ballot box and Parliament is left free to control national borders and create the optimal conditions for free trade. It does not involve encouraging greater popular participation in politics via constitutional reform. Indeed, the government has a rather old-fashioned view of democracy based on upholding parliamentary sovereignty in Westminster and reviving Britain's global role. Whilst the government has highlighted the democratic deficit in the EU, it has failed to recognise the democratic deficit at home, exacerbated by the 'Remain' votes in Scotland and Northern Ireland. Furthermore, the pursuit of unfettered free trade in Europe and beyond risks handing further power to corporations at the expense of the citizenry. There is a danger that these problems will become all the more palpable once they can no longer be blamed on membership of the European Union: disaffection with the EU may translate into even greater disaffection with Westminster politics.

One possible consequence is the descent into the 'dictatorship of the majority' (Wolf, 2016). Indeed, popular sovereignty, whilst an essential component of modern democracy, can easily slide into populism. For Bogdanor, 'the referendum is likely to presage a movement to the right-not to the traditional conservative Right, but to a populist and nationalist Right of the kind such as used to be represented by Enoch Powell and Margaret Thatcher' (Bogdanor, 2016, p. 350). By this he means a Right that promotes freedom of capital but not of people. There is always a risk that this may in turn slip into a form of fascism, united against a persecuted 'other' (Liddle, 2016). In such a scenario, the executive would blindly implement the wishes of the vocal majority, bypassing Parliament and the institutional checks and balances contained therein, no 
matter how imperfect they may be. Democracy itself would be threatened as the delicate balance that needs to be made between parliamentary and popular sovereignty is upset.

An alternative, more optimistic scenario is that the stripping bare of Britain's own democratic deficit might lead to demands for concrete constitutional reform in the UK, capable of providing a more modern, plural notion of parliamentary sovereignty whilst also respecting popular sovereignty by ensuring that the different voices of 'civil society' are given equal weight. Indeed, the 'Leave' vote might be regarded as a vote not against the EU but against a particular way of doing politics that empowers the elites and corporations over ordinary people. If regarded as such, the recent electoral successes of the Labour party led by Jeremy Corbyn might not seem so surprising. Should the current government collapse, leading to a Labour victory in general election before 2019, a very different form of Brexit is possible - one which empowers people over corporations, thus ensuring that post-Brexit democracy is no illusion.

Yet, ironically, should a conservative government remain in power, the most fertile terrain for demands for democratic renewal might prove to be within the EU as a whole range of new movements such as DIEM (Democracy in Europe Movement) are springing up to demand genuine democratic reform of EU institutions. The obstacle to reform lies not so much in the institutions of the EU but in national governments, particularly those of the Eurozone. Democratic movements must join forces to bring about change at a national level with a wider aim of instigating profound democratic change at a supranational level. Of course, the voice of these movements also risks being drowned out by right-wing populist clamour but there may be more chance of resisting anti-democratic forces when united with other nations rather than standing alone, especially with a free trade ideologue at the helm. 


\section{References}

Alexandre-Collier, A. (2016) 'How Populist was David Cameron?', Juncture, Vol. 23(2), pp. 116-125.

Ashcroft, Lord (2016) 'How the UK voted on Thursday... and why', 24 June. Available at «http://lordashcroftpolls.com/2016/06/how-the-united-kingdom-voted-and-why/» Accessed 16 January 2017.

Baker, D. and Schnapper, P. (2015) Britain and the Crisis of the European Union (Basingstoke: Palgrave Macmillan).

Barnett, A. (2016) Blimey in Could be Brexit. OpenDemocracy. Available at " https://drive.google.com/file/d/0B6iE9UndVXNKSIVfMkZ0RGNuN1k/view» Accessed 5 July 2017.

Bell, E. (2017) 'Shrinking the State? Change and continuity in public service reform', forthcoming.

Bell, E. (2015) Soft Power and Freedom under the Coalition (Basingstoke: Palgrave Macmillan).

Bell, S. and Hindmoor, A. (2009) Rethinking Governance: The centrality of the State in modern society (Cambridge: Cambridge University Press).

Boffey, D. and Doshi, V. (2016) 'India warns UK immigration policy could wreck trade deal', The Guardian, 6 November.

Bogdanor, V. (2016) 'Europe and the Sovereignty of the People', The Political Quarterly, Vol. 87(3), pp. 348-51.

Cameron, D. (2016) Speech following referendum on EU membership, 24 June.

Cameron, D. (2006) Speech to the Conservative Party Conference, 1 October.

Carswell, D. (2016) Twitter, 3 November. Available at «https://twitter.com/DouglasCarswell/status/794136296277110784» Accessed 16 January 2017.

Cassen, B. (2016) 'Le legs britannique à l’Europe', Le Monde Diplomatique, juillet.

Cooper, R. (2016) 'The European Union does not have a democratic deficit - it has a democratic surplus', LSE Blog on European Politics and Policy. Available at «http://bit.ly/1hIu4MH» Accessed 5 July 2017.

Corporate Europe (2015) 'TTIP: A corporate lobbying paradise', 14 July. Available at « https://corporateeurope.org/international-trade/2015/07/ttip-corporate-lobbyingparadise» Accessed 5 July 2017. 
Crouch, C. (2012 [2004] Post-Democracy (Cambridge: Policy Press).

Crouch, C. (2010) 'The Global Firm: The Problem of the Giant Firm in Democratic Capitalism', in Coen, D., Grant, W. \& Wilson, G. (eds.) The Oxford Handbook of Business and Government (Oxford: Oxford University Press), pp. 148-172.

Daily Express (2016) 'Brexit is a victory for democracy: Leave's bravery will usher in a golden era for us all', 24 June.

Deloitte (2016) The State of the State 2014-15: Implications for private sector outsources. Available at «http://www2.deloitte.com/content/dam/Deloitte/uk/Documents/bps/deloitte-ukstate-of-the-state-point-of-view.pdf» Accessed 5 July 2017.

Dodds, A. (2016) 'Why People Voted to Leave and What to Do Now?', The Political Quarterly, Vol. 87(3), pp. 360-364.

European Commission (2015) Standard Eurobarometer 83, Spring 2015: Public Opinion in the European Union. Available at «http://ec.europa.eu/public_opinion/archives/eb/eb83/eb83_publ_en.pdf» Accessed 5 July 2017.

European Union, 'Eur-Lex: Democratic Deficit'. Available at «http://eurlex.europa.eu/summary/glossary/democratic deficit.html?locale=en» Accessed 5 July 2017.

Fazi, T. (2015) 'The troika saved banks and creditors - not Greece', 25 January, openDemocracy. Available at " https://www.opendemocracy.net/can-europe-makeit/thomas-fazi/troika-saved-banks-and-creditors-\%e2\%80\%93-not-greece» Accessed 5 July 2017.

Farage, N. (2016) 'Nigel Farage's Post-Brexit Speech to the EU Parliament', 28 June. Available at «https://heatst.com/world/full-transcript-nigel-farages-post-brexitspeech-to-the-eu-parliament/» Accessed 5 July 2017.

Fox, L. (2017) 'Britain is embracing the brave new world of free trade', The Daily Telegraph, 19 January.

Gove, M. (2016) 'EU referendum: Michael Gove explains why Britain should leave the EU', The Daily Telegraph, 20 February.

IMF Independent Evaluation Office (2014) IMF Response to the Financial and Economic Crisis (Washington: IMF).

Johnson, B. (2016) 'I cannot stress too much that Britain is part of Europe - and always will be', The Daily Telegraph, 26 June.

Kadritzke, N. (2016) 'Grande braderie en Grèce', Le Monde Diplomatique, juillet. 
Krugman, P. (2015) 'The austerity delusion', The Guardian, 29 April.

Labour Party (2017) Labour Party Manifesto 2017: For the Many, Not the Few. Available at «http://www.labour.org.uk/index.php/manifesto2017» Accessed 10 August 2017.

Liddle, R. (2016) 'From Pain to a Plan', The Political Quarterly, Vol. 87(3), pp. 365-71.

LSE Diplomacy Commission (2015) Investing for Influence. Available at " http://www.lse.ac.uk/IDEAS/publications/reports/pdf/LSE-IDEAS-Investing-forInfluence.pdf» Accessed 5 July 2017.

May, T. (2017) ‘Brexit Speech’, 17 January.

Marquand, D. (1979) Parliament for Europe (London: Jonathan Cape).

Mattila, M. (2003) 'Why bother? Determinants of turnout in the European elections'. Electoral Studies, Vol. 22, pp. 449-468.

McCorkindale, C. (2016) 'Scotland and Brexit: The state of the union and the union state', King's Law Review, Vol. 27 (3), pp. 354-365.

Mortimer, J. (2016) 'Whether Britain stays in the EU or not, there's a democratic deficit that must be addressed', Democratic Audit UK, 9 January. Available at " http://www.democraticaudit.com/2016/01/09/whether-britain-stays-in-the-eu-ornot-theres-a-democratic-deficit-that-must-be-addressed/» Accessed 5 July 2017.

Pabst, A. (2014) 'After the Scottish No: The crisis of liberal democracy and the case for "mixed government"', Telos, Vol. 169, pp. 8-27.

R. (Miller) v. Secretary of State for Exiting the European Union [2016] EWHC 2768 (Admin)

Robert, A-C (2016) 'De l'art d'ignorer le peuple', Le Monde Diplomatique, October.

Schäuble, W. (2015), quoted by Varoufakis, Y. (2016) 'Why we must save the EU', The Guardian, 5 April.

Schnapper, P. (2014) Le Royaume-Uni doit-il sortir de l'Union européenne? (Paris : La documentation française).

Seaton, J. (2016) 'Brexit and the Media', The Political Quarterly, Vol. 87(3), pp. 333-337.

SPERI Sheffield Political Economy Research Institute (2015) 'What six public opinion graphs tell us about austerity', 9 July. Available at " http://speri.dept.shef.ac.uk/2015/07/09/public-opinion-graphs-austerity/» Accessed 5 July 2017. 
Terry, C. (2014) Tackling Europe's Democratic Deficit, The Electoral Reform Society. Available at «http://www.electoralreform.org.uk/sites/default/files/Close\%20the\%20Gap\%20FOR\%200NLINE\%204.pdf » Accessed 5 July 2017.

The Daily Mail (2017) Online version, 24 January. Available at «http://www.dailymail.co.uk/home/index.html» Accessed 5 July 2017.

The Daily Mail (2016) 'Enemies of the People', 3 November.

The Economist (2015) 'Of Rules and Order', 9 May.

The Telegraph (2016) 'Nigel Farage: $£ 350$ million pledge to fund the NHS was "a mistake"', 24 June.

Tonge, J. 'The Impact of Withdrawal from the EU upon Northern Ireland', Political Quarterly, Vol. 87 (3), pp. 338-342.

Trump, D. (2017a) Interview with Michael Gove, The Times, 16 January.

Trump, D. (2017b) Quoted in The Independent, 8 July 2017. Available at http://www.independent.co.uk/news/uk/politics/donald-trump-trade-deal-uk-veryquickly-g20-latest-meet-theresa-may-brexit-a7830226.html» Accessed 5 July 2017.

UK Political Info (2017) 'European Parliament Election Turnout 1979-2014'. Available at «http://www.ukpolitical.info/european-parliament-election-turnout.htm» Accessed 5 July 2017.

Walker, P. (2017) “'Soft Brexit” policy won Labour votes in general election, says study', The Guardian, 1 August.

Wolf, M. (2016) 'Appeals to the popular will threaten parliamentary sovereignty', Financial Times, 8 December.

Wren-Lewis, S. (2016a) 'A General Theory of Austerity', Blavatnik School of Government Studies, Working Paper 2016/014. Available at «https://www.bsg.ox.ac.uk/sites/www.bsg.ox.ac.uk/files/documents/BSG-WP-2016014.pdf» Accessed 5 July 2017.

Wren-Lewis, S. (2016b) 'More on Brexit and the Politicisation of the Truth', Mainly Macro Blog, 20 June. Available at « https://mainlymacro.blogspot.fr/2016/06/more-onbrexit-and-politicisation-of.html» Accessed 5 July 2017. 